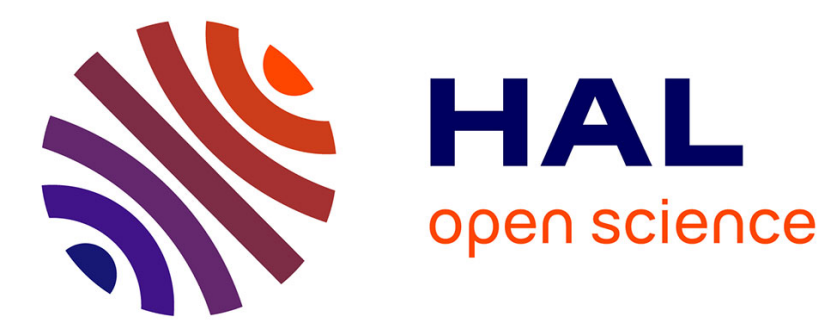

\title{
Forest canopy studies as an emerging field of science
}

\author{
Nalini Nadkarni, Geoffrey Parker, Margaret Lowman
}

\section{To cite this version:}

Nalini Nadkarni, Geoffrey Parker, Margaret Lowman. Forest canopy studies as an emerging field of science. Annals of Forest Science, 2011, 68 (2), pp.217-224. 10.1007/s13595-011-0046-6 . hal00930781

\section{HAL Id: hal-00930781 \\ https://hal.science/hal-00930781}

Submitted on 1 Jan 2011

HAL is a multi-disciplinary open access archive for the deposit and dissemination of scientific research documents, whether they are published or not. The documents may come from teaching and research institutions in France or abroad, or from public or private research centers.
L'archive ouverte pluridisciplinaire HAL, est destinée au dépôt et à la diffusion de documents scientifiques de niveau recherche, publiés ou non, émanant des établissements d'enseignement et de recherche français ou étrangers, des laboratoires publics ou privés. 


\title{
Forest canopy studies as an emerging field of science
}

\author{
Nalini M. Nadkarni • Geoffrey G. Parker • \\ Margaret D. Lowman
}

Received: 24 November 2010 / Accepted: 30 November 2010/Published online: 5 April 2011

(C) INRA and Springer Science+Business Media B.V. 2011

\section{Introduction}

Scientific fields go through stages of maturity, as do plants, people, and societies. A scientific field in its infancy is typified by descriptive studies by individual scientists who identify phenomena and document patterns. As a field matures, investigations involve multiple researchers who address process-oriented questions to explain the observed patterns. A sign of maturity for a field is when its scientists can validate predictive models and relate findings to those of other fields (Lodahl and Gordon 1972).

Studies of the forest canopy-"the aggregate of all crowns in a stand of vegetation" (Parker 1995) - constitute a scientific field that has passed through some of these stages with remarkable speed, but has not yet attained all of the attributes of full maturity. Thirty years ago, the canopy was considered an insignificant part of the forest ecosystems with little scientific attention beyond a few taxonomists specializing in arboreal biota. The development of three technological innovations coincided with the subsequent rapid growth of canopy studies: (1) mountain-

\section{Handling Editor: Erwin Dreyer}

N. M. Nadkarni $(\square)$

The Evergreen State College,

Olympia, WA 98505, USA

e-mail: nadkarnn@evergreen.edu

\section{G. G. Parker}

Smithsonian Environmental Research Center,

Edgewater, MD 21037, USA

e-mail: parker@si.edu

\section{D. Lowman}

NC Museum of Natural Sciences/NC State University,

Raleigh, NC 27601, USA

e-mail: Canopymeg@gmail.com climbing methods, fogging techniques, and construction equipment to facilitate access (Erwin 1982; Moffett and Lowman 1995); (2) easy-to-use equipment for making whole canopy measurements of material and energy exchanges with the atmosphere (Baldocchi et al. 1988), and (3) methods to measure the structure of whole canopies (e.g., LIDAR, Gonzalez et al. 2010).

Canopy studies relate to the field of forest ecology, and related fields: e.g., atmospheric sciences, entomology, vertebrate biology, and soil science. A growing literature and textbooks now document our expanding knowledge of the composition, structure, and function of canopy biota, and their responses to changes in environmental conditions (Lowman and Rinker 2004; Lowman and Moffett 1993; Lowman and Nadkarni 1995; Mulkey et al. 1996), including general review papers (Lowman 2009; Parker and Brown 2000) and reviews of specific topics, e.g., epiphytes (Benzing 1990), canopy insects (Basset et al. 2003), and tree physiology (Ryan 2002). Canopy symposia are convened at scientific meetings, and international canopy conferences are held every 4 years. Formal networks exist for communication among researchers. Effects of human activities on canopy biota have been documented at the global level, particularly for climate change and forest fragmentation (Nadkarni and Solano 2002; Ozanne et al. 2003). Canopy research has extended into the policy arena, on issues such as Reducing Emissions from Deforestation and Forest Degradation. This work has received increasing public interest, manifested in popular publications (e.g., Moffett 1993), and numerous media pieces.

However, certain aspects to support a vigorous field of science have not yet been attained. A canopy resources website ("the Big Canopy Database") was initiated in 1999, but support has been based on short-term funding (McIntosh et al. 2007). An attempt to create a journal 
devoted to canopy research failed. No formal graduate training program exists, despite strong interest on the part of many graduate students. No centralized clearinghouse for funding for canopy research or education exists (as do for such fields as marine biology and horticulture).

Canopy researchers now ponder which directions they should choose for the future. In this paper, we synthesize recent discussions into a framework of past, present, and future perspectives, framed by a quantitative analysis of the research history of our field using the approach of scientometrics. Specifically, we: (1) summarize the history of the field; (2) quantitatively assess the field by a bibliographic analysis of scientific citations to infer trends of authorship, content, geographic location, and themes; and (3) draw integrative questions and themes. This paper was inspired by the 5th International Canopy Conference, in Bangalore, India (October 2009).

\subsection{Definition and scope of canopy studies}

Canopies are a characteristic feature of the land surface of our planet. The total foliage surface area of terrestrial vegetation $\left(644 \times 10^{6} \mathrm{~km}^{2}\right)$ is greater than the surface area of the entire earth $\left(510 \times 10^{6} \mathrm{~km}^{2}\right)$ (Whittaker and Likens 1974). Researchers have viewed the canopy in various ways: (1) as a place (whose location can be defined, either by reference to relative height, by the proximity of nonforest conditions, or even by the difficulty of access); (2) as a set of conditions (a medium with structural limits or environmental boundaries); or (3) as an interface between two environments, the atmosphere and biosphere. Canopies are common to all vegetation, but we focus here on the canopies of forests.

\subsection{Historical aspects of canopy research}

Early studies of the forest canopies, starting in the 1950s, were first undertaken by individual researchers, often in farflung locales, working on natural history observations of particular canopy biota. These first studies (e.g., Bawa 1974; Daubenmire 1959) tended to be carried out by a few individuals who did not use standardized methods. With the advent of new canopy access methods in the 1980s (Perry 1978), researchers became aware of the tremendous biodiversity of the canopy flora and fauna, particularly insects. Canopy fogging experiments transformed the way taxonomists viewed rainforest diversity, with the treetops harboring vast numbers of canopy specialists and generalists (Erwin 1982).

Early studies focused on natural history and forest structure issues (Sillett 1999), and later topics such as production, mortality, life histories, phenology, fruit dispersal, gene flow, herbivory, arthropod diversity (e.g.,
Basset et al. 2003), and epiphyte physiology (e.g., Zotz and Hietz 2001) were added. The scope later broadened to encompass larger spatial scales and a greater complexity of interactions. Descriptive studies, while continuing, gave way to process-oriented and mechanistic studies. In the early 1980s, ecologists documented the canopy as an "independent but related subsystem" of forests (Carroll 1980), its constituents and processes being critically important for community- and ecosystem-level processes such as nutrient cycling, hydrology, pollination, and herbivory (Coxson and Nadkarni 1995). More recently, canopy researchers enumerated the many ecosystem services that the canopy provides: major photosynthetic machinery, control of organic matter production; influence on the exchange of energy and matter with the atmosphere; microclimate effects; habitat for organisms; and contribution to the stability of world climate (Ozanne et al. 2003).

The growing body of knowledge is helping us understand: (a) the tremendous biodiversity in canopies, (b) the relationship between forest canopy structure and function, (c) the exchange of matter and energy with the atmosphere, and (d) the control of forests over climate (e.g., Bonan 2008). These issues relate to some of the most pressing environmental topics today: the loss of biodiversity, the functional role of forests to provide ecosystem services, and mitigation of global and regional climate change due to human activities. Research approaches have become more experimental and predictive in orientation (Winkler et al. 2005). Thus, the research has great promise for the integrative, comparative, and predictive work that marks a mature science.

This growing understanding has also created increased public interest in canopies and forests, with ramifications for conservation, environmental education, and ecotourism (Moffett 1993). Owing to the drama of climbing tall trees, the "frontier" nature of these studies (Preston 2007), and the aesthetic appeal of many canopy biota, non-scientific canopy issues have arisen, e.g., canopy ecotourism, adventure education, and the ethics of recreational treeclimbing. Citizen-science research to solve certain canopy questions has recently been implemented (Morisette et al. 2009).

\section{Scientometric approach to canopy studies}

Retrospective reviews on canopy studies have heretofore used qualitative approaches. We introduce a scientometric approach (the development, measurement, and selforganization of scientific communications, White and McCain 1998) to quantitatively analyze attributes of this field. We gathered and analyzed the peer-reviewed scien- 
tific articles concerned with forest canopies to address the following questions:

1. Which topics do canopy researchers study?

2. Where are canopy study sites and canopy researchers located?

3. How much do canopy researchers collaborate?

4. Which journals publish canopy research?

5. At what rate are citations produced; and how does this compare with the rates in other fields of science?

We used the Web of Science database (science citations only) administered through the University of Washington Library. On 6 September 2009, we searched for all articles and reviews of topics relating to tree and forest canopies, and arboreal and epiphytic biota. The specific search statement for title and keywords was: (((forest and canop*) or epiphyt* or arboreal or (tree and canop*) or canop*)). The time frame was for papers written between 1900 and 2008 in the following categories: ecology, forestry, environmental sciences, biodiversity, entomology, ornithology, microbiology, mycology, evolutionary biology, remote sensing, physiology, anatomy, and urban studies. We excluded these fields: geology, medicine, engineering, computer science, psychology, materials science, astronomy, chemistry, and physics. Note that we found papers that used the terms "forest canopy" and "tree canopy" in the title or keywords, so we may have missed some papers that reported on forest canopies without using those words in titles or keywords. Also, scientists from the United States (and other English-speaking countries) would use the term "canopy" more frequently than their nonEnglish-speaking counterparts, so there may have been a bias toward papers from English-speaking countries.

Downloaded citations were exported into an Excel dataset, with the following fields: authors, address and email for corresponding author, year of publication, title of article, journal name, volume, page numbers, and abstract. Location of study area (country) was determined from the abstracts of all of the papers; about $70 \%$ of these had site location. Location of the authors (country) was from the address of the communicating author. From the title and abstract, we assigned each of the citations into one of eight categories: plants, vertebrates, forest structure, remote sensing, invertebrates, physiology, forest/atmosphere interactions, and ecosystem ecology. We divided the vertebrate category into: herpetofauna, birds, marsupials, bats, primates, and other mammals.

\section{Results}

\subsection{Bibliographic characteristics}

Our database contained 5,411 references: 5,282 articles and 129 reviews. The sum of the number of journal pages was
59,394 , the equivalent of 237 standard length academic books of 250 pages each. The categories of studies were distributed unevenly among subject categories, with fewest concerning remote sensing, and the greatest number comprising vertebrates (Fig. 1). The most common category was vertebrates, with $27 \%$ of all studies (1,462 papers). The studies on vertebrates were dominated by birds, with similar numbers of the other vertebrate types (Fig. 2).

A total of 92 countries were represented. The top ten countries produced $75 \%$ of the papers; the USA was the largest (36\%), with others of the "top ten" comprising 2 $10 \%$ each (Fig. 3). The nationalities of authors of all papers were also biased toward North America and Europe, with tenfold more authors in the temperate vs. tropical zone by the number of citations ( 4,481 vs. 434 , respectively). However, nearly equal numbers of countries (47 vs. 45) were represented in the two zones.

Although canopy research has been carried out on every continent, the greatest number of studies took place in North America, followed by South America, Europe, Australia, Asia, with by far the fewest in Africa. The top ten countries were balanced between tropical and temperate nations (Fig. 4). The locations of study sites were generally similar to the nations of the home institutions of the authors, but not surprisingly, developed countries had more representation than developing countries.

Canopy citations were published in 353 journals, which reflects the very broad nature of the field. However, about $95 \%$ of these journals published fewer than three articles. The top ten journals each had more than 200 citations, and were spread over many disciplines (Table 1). We used the number of co-authors as a surrogate for the amount of collaboration among researchers. The mean number of coauthors was 2.0 for all years (median of 4.3); the maximum number of co-authors was 42 (Fig. 5).

The dynamics of publications showed a striking and rapid increase. Between 1990 and 1991, there was a marked increase in publications (252 to 857; Fig. 6). Assuming a $2-$

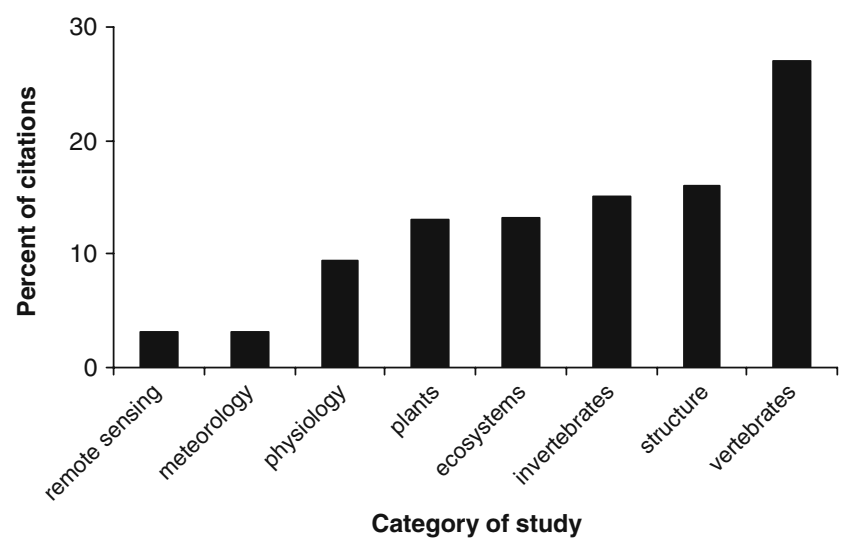

Fig. 1 Distribution of subject categories of canopy citations 


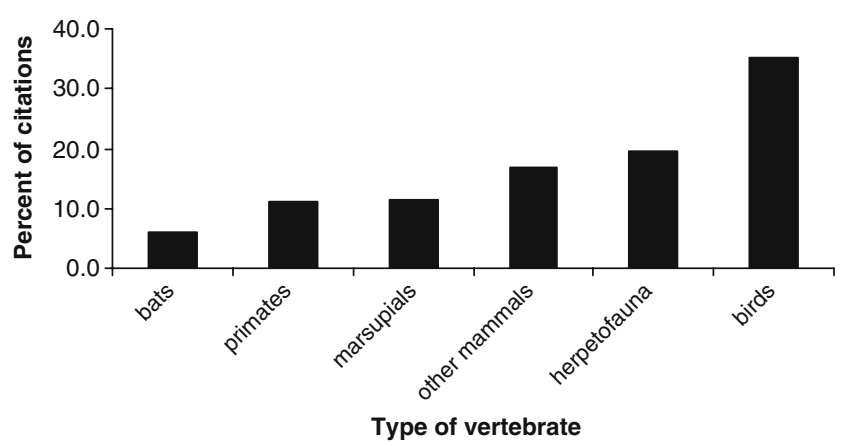

Fig. 2 Distribution of studies among types of vertebrates

3 years delay from fieldwork to publication, this pattern indicates that activities were burgeoning during 1987-1989. The number and diversity of journals and amount of collaboration also increased strikingly, as indicated by the increasing number of authors over time. The latter two trends are not surprising, as the number of journals and number of authors tend to be correlated with the number of published papers.

We compared the rate of growth of publications in the field of canopy studies to those in other fields, ecology and geology. Using the same techniques as above (with "ecology" and "geology" in the subject title), we documented the rate of publications by year. The slope of the line indicating the rate of growth of canopy studies and ecology were similar, but the rate of publications for geology was much slower (Fig 7).

\subsection{Content of canopy studies}

We identified four major research questions that have emerged in the last three decades:

1. How do interactions between species in the canopy differ from that of other vegetation components?

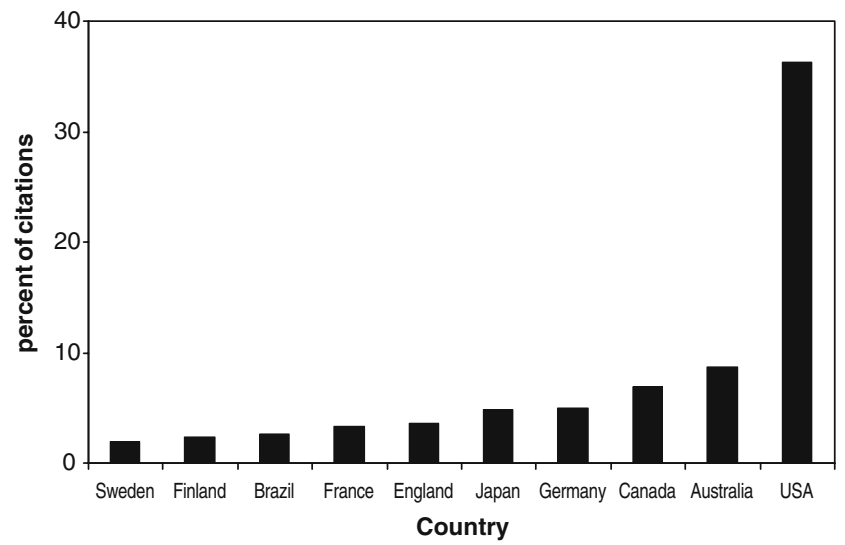

Fig. 3 Distribution of authors in the top ten countries

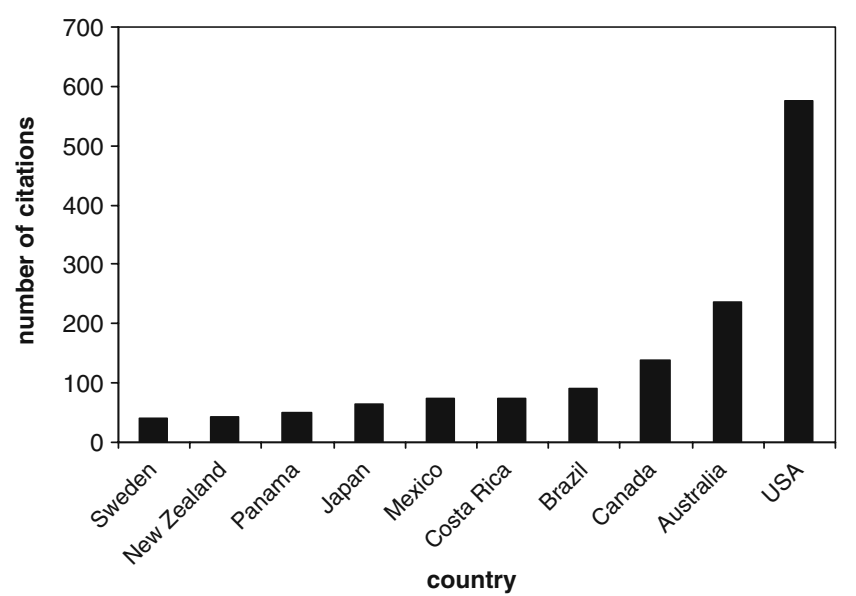

Fig. 4 Distribution of study sites in the top ten countries

2. How do species characteristics (e.g., body size and shape, metabolic costs) vary within and between canopies?

3. Would gradients (e.g., sun-shade, crown-ground) or definable zones be more useful than discrete units (e.g., height above ground) to understand canopy distributions?

4. How do human activities (e.g., alteration of global climate, landscape modification) affect the diversity and functioning of canopy biota?

\section{Discussion}

In a relatively short time, canopy research has had a tremendous impact on our understanding of forest biodiversity

Table 1 The percent of papers in each of the ten most common journals used by canopy researchers

\begin{tabular}{lc}
\hline Journal name & Percent of citations \\
\hline Trees-Structure and Function & 5.0 \\
Global Change Biology & 5.1 \\
Biological Conservation & 5.8 \\
Ecology & 7.4 \\
Journal of Tropical Ecology & 7.7 \\
Biotropica & 10.3 \\
Oecologia & 11.9 \\
Canadian Journal of Forest Research & 13.0 \\
Tree Physiology & 14.6 \\
Forest Ecology and Management & 19.2 \\
\hline
\end{tabular}

Note the broad range of subject areas, which includes forestry, ecology, conservation, and global change biology. The total number of citations is 5,411 


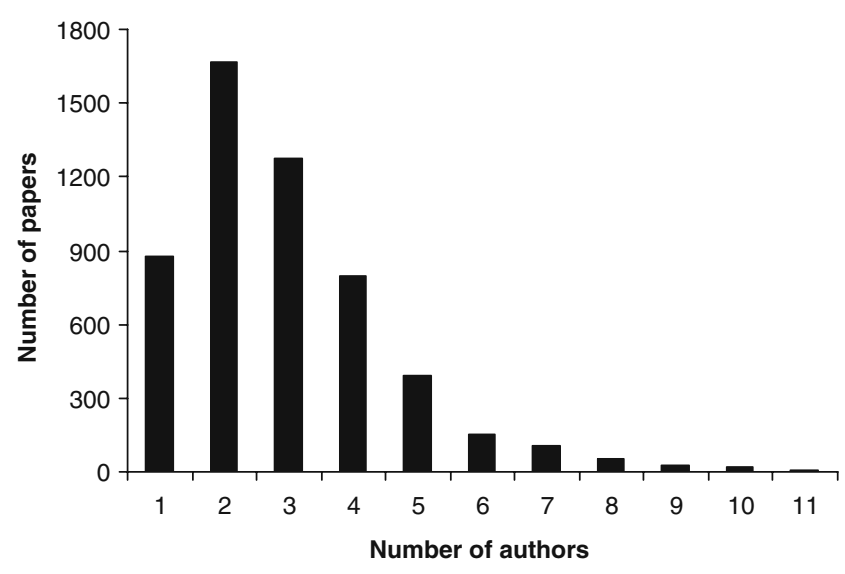

Fig. 5 Number of co-authors per paper, used as an indicator of the degree of collaboration among canopy researchers

and ecology. For example, insecticidal fog sampling of canopy biota led to revised estimates of the number of species on earth (Erwin 1982), and although the number is now believed to be lower than that original estimate, it is still double the number previously accepted. New patterns of flowering, novel breeding, and pollination systems in plants (Bawa 1990), and new insights to the role of epiphytes in nutrient dynamics have been documented (Nadkarni 1981). Stable isotopes have traced critical links between canopy and forest floor, elucidating the complex processes of forest food webs (Pringle and Fox-Dobbs 2008). At a larger scale, hydrologists have highlighted the important role the canopies play in regulating rainfall in the tropics (Calheiros and de Antonio 1990).

4.1 Novel contributions of canopy research and its integration with other fields

The scientific literature on forest canopies is diverse and comprises multiple disciplines. Canopy researchers have applied a variety of methods for canopy access, sampling and sensing, and process measurements, which has galva-

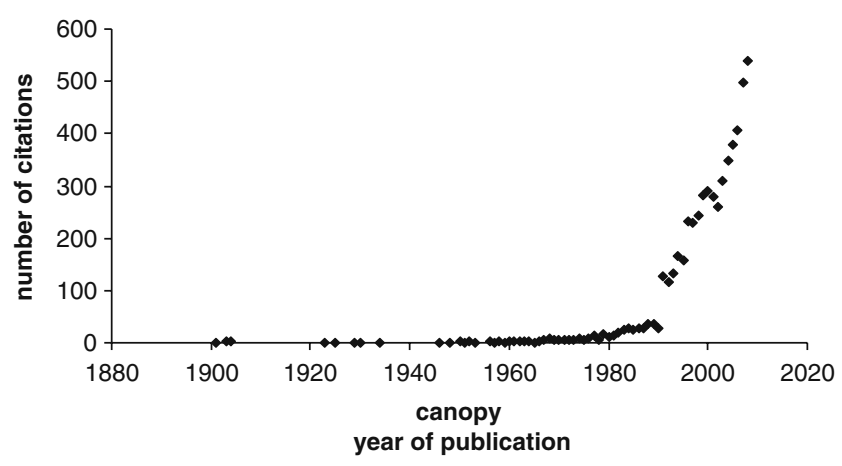

Fig. 6 Rate of canopy citations published from 1901 to 2008

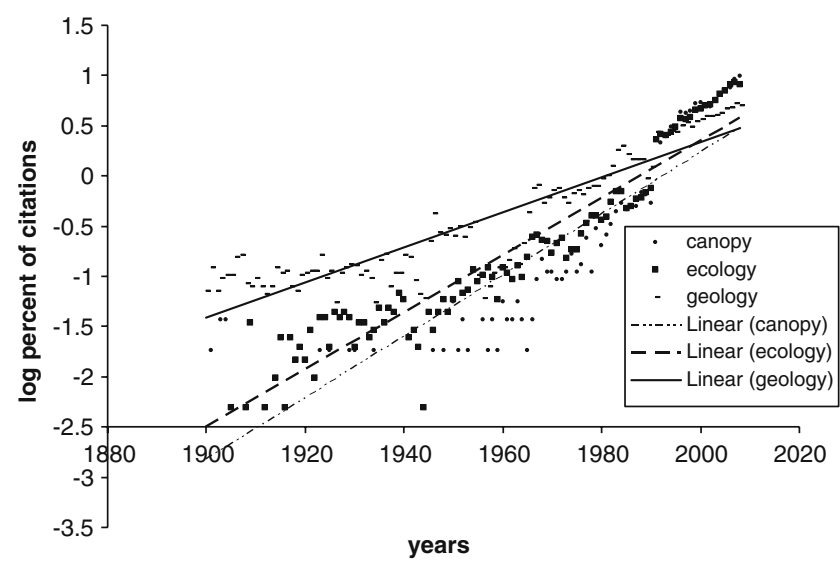

Fig. 7 Comparison of rates of citations publications for the fields of canopy studies, ecology, and geology

nized substantial changes in how we think about canopies. For example, forest canopy structure ("the organization in space and time of the above-ground components of vegetation," Parker 1995) is a critical link to understand many functions of canopies and for distinguishing among canopies. Concepts of the shape of vegetation have been derived from the size and spatial distribution of gaps (Hubbell et al. 1999), the topography of the outer surface (Nakashizuka et al. 1995), vertical profiles of leaf area, and spatial distribution of crowns (Van Pelt and North 1996). Remote sensing tools provide canopy visualization from above, incorporating surface topographic features, with wide coverage at coarse resolution (e.g., Lovell et al. 2003). We now understand that the same canopy may be seen very differently: as an environmental gradient, as a community of leaves, a medium for radiation exchange, a branching network of stems, a complex topographic landscape, a mosaic of climates, or a reticulum of voids (Nadkarni et al. 2008).

Canopy elements participate in the capture, retention, and diversion of materials at the ecosystem level. Early studies of single canopies documented movements of materials transported in organic matter or dissolved form in rain-, soil-, and stream-water within the canopy (Carroll 1980). Later, landscape- and ecosystem-level studies showed that canopy components affect the circulation and storage of macronutrients, which is critical for gaseous fixation and wet and dry deposition (Coxson and Nadkarni 1995). Early ecosystem studies of canopies deduced processes and behavior of parts using observations of the differences between material and energy inputs to and outputs from canopies (Johnson and Lindberg 1992). It was not until experiments were made on canopy tissue samples that the mechanisms (e.g., gaseous absorption) and true rates of exchange could be measured (Morisette et al. 2009). 


\subsection{Dynamics of canopy research}

The canopy research community has progressed from largely personal connections to networked interactions. Studies are increasingly becoming collaborative and comparative. The rapid rise in the rate of publications in 1990-1991 can be explained in several ways. It may simply be that authors used the word "canopy" more frequently than they did before, even though they had been working on canopies and used the words "treetop" or "arboreal," which would not have been captured in our search.

Another reason is the creation and fostering of communication and cooperation among canopy scientists. Progress in interconnecting canopy researchers is accelerating through the

Table 2 Progression of development for scientific fields

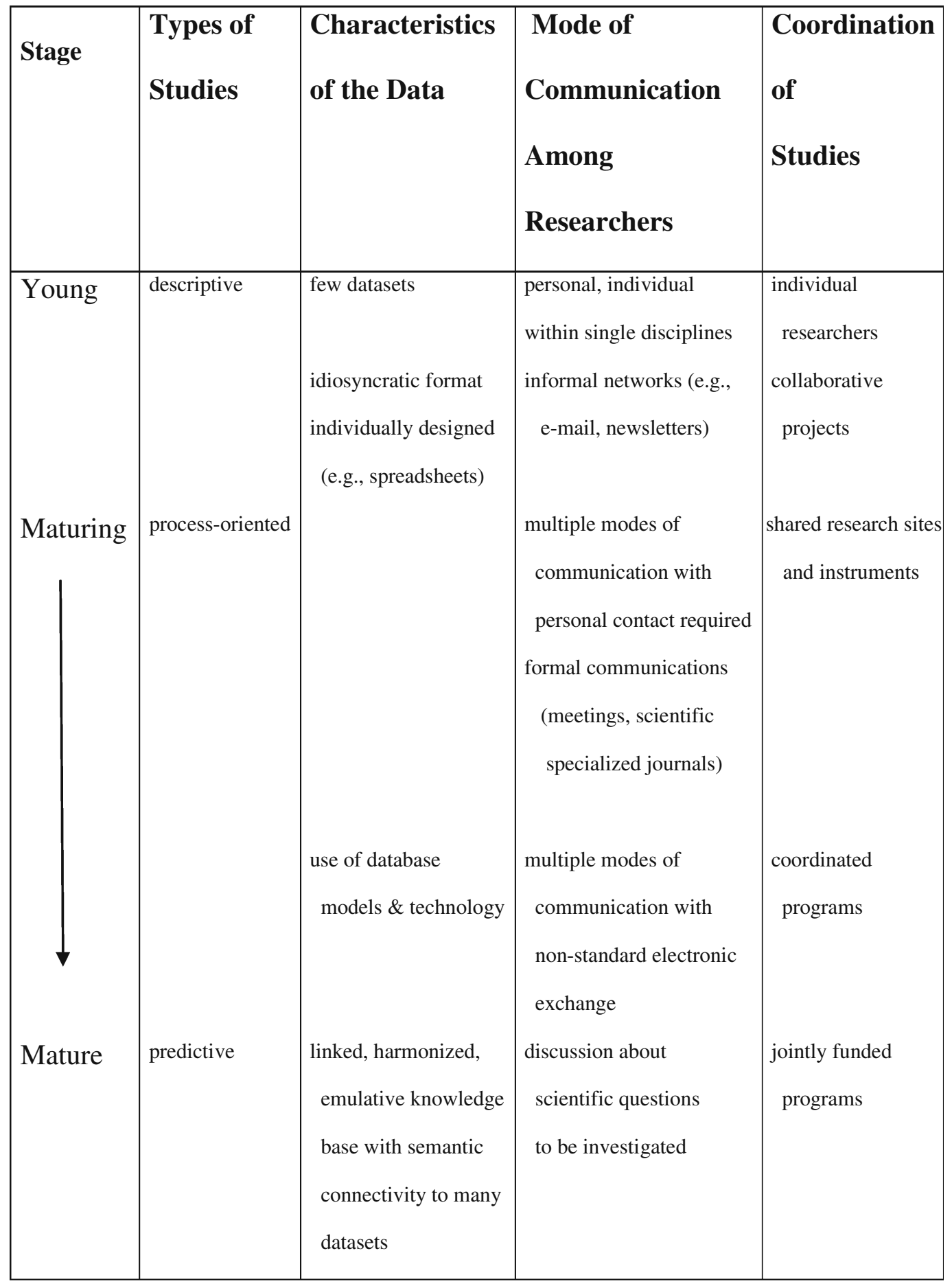


establishment of networks that promote regular, focused, and information-rich communication: the International Canopy Network (www.evergreen.edu/ican) was formed to enhance communication among canopy researchers (Nadkarni and Parker 1994). The Oxford-based Global Canopy Program (www.globalcanopy.org) provides scientifically sound information to policy makers. A loose network of canopy cranes exists (http://www.stri.org/english/research/facilities/terrestrial/ cranes/canopy_crane_network.php). Meetings, workshops, and symposia on canopy topics are now common.

\subsection{Whither canopy studies?}

The study of forest canopies is now at a crossroads. On one hand, it enjoys major attention because of the current global priorities of biodiversity, sustainability, and climate change. On the other hand, some of the basic constituents of mature sciences still do not exist: e.g., a dedicated scientific journal, internationally accessible graduate programs, and presence of canopy scientists in major advisory positions on scientific boards. One possible explanation for lack of these elements is that the canopy research lacks corporate sponsors (as compared to fisheries, marine ecology, or climate change, fields that have obvious champions in industry).

The topic of forest canopies provides a springboard from which to teach a broad range of environmental issues. Because the biosphere is driven by solar energy, the top of the forest the is a logical place from which to launch into topics that include light capture, the implications of airborne pollutants, food chains, and relationships between people and their surroundings. Several environmental education programs have incorporated canopy-specific information into school curricula to meet state-imposed requirements for environmental education. This topic is inherently attractive and compelling to children.

Advances in canopy research will need cooperative and comparative studies, and some of these are underway. For example, recent attempts to understand local controls and large-scale patterns of carbon exchange have been addressed by coordinated groups such as FLUXNET. The ability to get and use data from other research efforts is now being overcome (Nadkarni and Parker 1994). Canopies have often been studied in situations that are simple and extensive, but researchers are now investigating human-affected landscapes, which are patchy, with distinct "edges" (Chen et al. 1993; Barthlott et al. 2001). Canopy researchers have enumerated the many ecosystem services that canopy biota provide (Ozanne et al. 2003), including carbon, nutrient, and water storage. Thus, in this millennium, canopy studies and researchers have, to some extent, "come of age," gaining greater visibility from public audiences and scientific credibility from academics.

In conclusion, canopy studies have produced a great deal of peer-reviewed information in diverse fields, the minimal equivalent of eight books per year for 30 years. Forest canopy studies have fundamentally altered our perception of woody vegetation, as the traditional ground-based vantage has been inadequate to understand many forestbased questions. This young field is relatively free of the limitations of inherited concepts and some of the social constraints that hamper older disciplines. Our synthesis (Table 2) depicts a field that has grown in response to physical access to the canopy, but which has also developed conceptually. The field began with descriptive studies, small and un-coordinated datasets, questions that were curiosity-driven and with few links to the public. In the present and foreseeable future, projects are experimental or modeling in approach, better coordinated, and of much greater relevance and interest to society.

Acknowledgments We thank the Wind River Canopy Crane Research Facility and The Helen R. Whiteley Center (University of Washington). Research Grants from the NSF provided support (DEB 99-75510, BDEI 04-17311, DEB 05-42130, and DEB 09-56301 to NN). Maureen Nolan of the University of Washington Library and Sultana Shah Jefts helped with data analyses. The International Canopy Network provided access to archived canopy citations. Portions of this paper were prepared for the 5th International Canopy Conference in Bangalore, India, supported by an NSF grant to Kamal Bawa and ML (OISE0938756).

\section{References}

Baldocchi DD, Hicks BB, Meyers TP (1988) Measuring biosphereatmosphere exchange of biologically related gases with micrometeorological methods. Ecology 69:1331-1340

Barthlott W, Schmit-Neuerburg V, Nieder J, Engwald S (2001) Diversity and abundance of vascular epiphytes: a comparison of secondary vegetation and primary montane rain forest in the Venezuelan Andes. Plant Ecol 152:145-156

Basset Y, Novotny V, Miller SE, Kitching RL (eds) (2003) Arthropods of tropical forests. Spatio-temporal dynamics and resource use in the canopy. Cambridge University Press, Cambridge, 540 p

Bawa KS (1974) Breeding systems of tree species of a lowland tropical community. Evolution 28:85-92

Bawa KS (1990) Plant-pollinator interactions in tropical lowland rain forest. Ann Rev Ecol Syst 21:399-422

Benzing D (1990) Vascular epiphytes: general biology and related biota. Cambridge University Press, Cambridge, $256 \mathrm{p}$

Bonan GB (2008) Forests and climate change: forcings, feedbacks, and the climate benefits of forests. Science 320:1444-1449

Carroll GL (1980) Forest canopies: independent and complex subsystems. In: Waring RH (ed) Forests: fresh perspectives from ecosystem analysis. Oregon State University Press, Corvallis, pp $87-107$

Calheiros R, Antonio M de A (1990) Nowcasting for agriculture with the Sao Paulo radar network. Weather Radar Networking (Cost Project 73). Kluwer Academic, New York

Chen JJ, Franklin JF, Spies TA (1993) Contrasting microclimate patterns among the clearcut, edge, and interior area of old-growth Douglas-fir forests. Agr For Met 63:219-239

Coxson D, Nadkarni NM (1995) Nutrient cycling in forest canopies. In: Lowman MD, Nadkarni NM (eds) Forest canopies. Academic Press, New York, pp 495-543 
Daubenmire R (1959) A canopy-coverage method of vegetation analysis. Northwest Sci 33:43-64

Erwin T (1982) Tropical forests: their richness in Coleoptera and other arthropod species. Coleop Bull 36:74-75

Gonzalez P, Asner GP, Battles JJ, Lefsky M, Waring KM, Palace M (2010) Forest carbon densitites and uncertainties from Lidar, QuickBird, and field measurements in California. Rem Sens Environ 114:1561-1575

Hubbell SP, Foster RB, O’Brien ST, Harms KE, Condit R, Wechsler B, Wright SJ, Loo de Lao S (1999) Light-gap disturbances, recruitment limitation, and tree diversity in a Neotropical forest. Science 283:554-557

Johnson DW, Lindberg SE (eds) (1992) Atmospheric deposition and forest nutrient cycling - a synthesis of the Integrated Forest Study. Springer, New York, $256 \mathrm{p}$

Lodahl J, Gordon G (1972) The structure of scientific fields and the functioning of university graduate departments. Amer Sociol Rev 37:57-72

Lovell JL, Jupp DLB, Culvenor DS, Coops JC (2003) Using airborne and ground-based ranging lidar to measure canopy structure in Australian forests. Can J Rem Sens 29:607-622

Lowman MD (2009) Canopy research in the twenty-first century: a review of arboreal ecology. Trop Ecol 50:125-136

Lowman MD, Moffett M (1993) The ecology of tropical rain-forest canopies. Trends Ecol Evol 8:104-107

Lowman MD, Nadkarni NM (eds) (1995) Forest canopies. Academic, New York, $322 \mathrm{p}$

Lowman MD, Rinker B (eds) (2004) Forest canopies, 2nd edn. Academic, New York, $335 \mathrm{p}$

McIntosh ACS, Cushing JB, Nadkarni NM, Zeman L (2007) Database design for ecologists: composing core entities with observations. Ecolog Inform 2:224-236

Moffett MW (1993) The high frontier-exploring the tropical rainforest canopy. Harvard University Press, Cambridge, $267 \mathrm{p}$

Moffett MW, Lowman MD (1995) Canopy access techniques. In: Lowman MD, Nadkarni NM (eds) Forest canopies. Academic Press, New York, pp 3-26

Morisette JT, Richardson AD, Knapp AK, Fisher JI, Graham EA, Abatzoglou J, Wilson BE, Breshears DD, Henebry GM, Hanes JA, Liang L (2009) Tracking the rhythm of the seasons in the face of global change: phenological research in the 21 st century. Front Ecol Environ 7:253-260

Mulkey SS, Chazdon R, Smith AP (1996) Tropical forest plant ecophysiology. Chapman and Hall, New York, $343 \mathrm{p}$

Nadkarni NM (1981) Canopy roots: convergent evolution in rainforest nutrient cycles. Science 213:1024-1025
Nadkarni NM, Parker GG (1994) A profile of forest canopy science and scientists - who we are, what we want to know, and obstacles we face: results of an international survey. Selbyana 15:38-50

Nadkarni NM, Solano R (2002) Potential effects of climate change on canopy communities in a tropical cloud forest: an experimental approach. Oecologia 131:580-584

Nadkarni NM, McIntosh ACS, Cushing JB (2008) A conceptual framework to categorize perceptions and understanding of forest structure. For Ecol Manage 256:872-882

Nakashizuka Y, Katsui T, Tanaka H (1995) Forest canopy structure analyzed by using aerial photographs. Ecol Res 10:13-18

Ozanne CM, Anhuf D, Boulter SL, Keller M, Kitching RL, Korner C, Meinzer FC, Mitchell AW, Nakashizuka T, Dias P, Stork NE, Wright SJ, Yoshimura M (2003) Biodiversity meets the atmosphere: a global view of forest canopies. Science 301:183-186

Parker GG (1995) Structure and microclimate of forest canopies. In: Lowman MD, Nadkarni NM (eds) Forest canopies. Academic, New York, pp 73-106

Parker GG, Brown MJ (2000) Forest canopy stratification-is it useful? Amer Nat 155:473-484

Perry DR (1978) A method of access into crowns of emergent and canopy trees. Biotropica 10:155-157

Preston R (2007) The wild trees. Random House, New York, 322 p

Pringle RM, Fox-Dobbs K (2008) Coupling of canopy and understory food webs by ground-dwelling predators. Biotropica 11:13281337

Ryan MG (2002) Canopy processes research. Tree Physiol 22:10351043

Sillett SC (1999) Tree crown structure and vascular epiphyte distribution in Sequoia sempervirens rain forest canopies. Selbyana 20:76-91

Van Pelt R, North MP (1996) Analyzing canopy structure in Pacific Northwest old-growth forests with a stand-scale crown model. Northwest Sci 70(Special issue):15-30

White HD, McCain KW (1998) Visualizing a discipline: an author cocitation analysis of information science, 1972-1995. J Amer Soc Infor Sci 49:327-355

Whittaker RH, Likens GE (1974) The primary production of the biosphere. Hum Ecol 1:299-369

Winkler M, Hulber K, Hietz P (2005) Effect of canopy position on germination and seedling survival of epiphytic bromeliads in a Mexican humid montane forest. Ann Bot 95:1039-1047

Zotz G, Hietz P (2001) The physiological ecology of vascular epiphytes: current knowledge, open questions. J Exp Bot 52:2067-2078 